\title{
Leituras de Max Martins: a universidade do poeta
}

\author{
Max Martin's readings: the university of the poet
}

Elias Ribeiro PINTO*

Em uma de nossas conversas, pedi ao Max Martins que traçasse um roteiro de sua formação poética, leituras, seus santos de cabeceira, ab ovo, desde o berço. Ele, então, me preparou esse roteiro em que mapeia sua formação como leitor. O texto foi publicado, originalmente, na coluna que eu, na época, assinava no jornal A Província do Pará, ali por volta de 1990/91 (o recorte que eu guardei não traz a data da edição). Fiquem com as leituras de Max da Rocha Martins, que permanecem vivíssimas (como a obra do poeta). Ele nos deixou, aos 82 anos, em 9 de fevereiro de 2009. A propósito, sua obra - aproveito para insistir - continua pedindo imediata reedição.

O meu livro, Para Ter Onde Ir, ainda inédito [veio a ser publicado em 1992], tem uma dedicatória: “Ao Velho Poeta". Aparentemente simples, levará porém os futuros leitores à interrogação: quem é esse Velho Poeta? O Velho Poeta é muitos poetas, escritores, romancistas, filósofos, ensaístas, amigos, meus pais; aqueles que direta ou indiretamente tiveram vívida influência sobre a minha formação de poeta. Aqueles que pelas suas obras ou pela amizade criadora, ou por seus exemplos, teceram o que eu chamaria a minha universidade. Assim, pois, o Para ter onde ir, que é um diálogo comigo mesmo, é dedicado, afinal, a mim próprio.

\footnotetext{
* Artigo publicado no Jornal O Liberal, de Belém do Pará.
}

Recebido em 27 de novembro de 2016. Aprovado em 30 de novembro de 2016. 
No princípio foi Casemiro de Abreu, os poetas românticos brasileiros e portugueses das velhas antologias. Depois veio o Cartas a um jovem poeta, de Rainer Maria Rilke, o primeiro presente recebido do professor Francisco Paulo Mendes e cujo exemplar muitos anos depois passei às mãos merecedoras do poeta Age de Carvalho. Depois vieram Carlos Drummond de Andrade, Jorge de Lima, Murilo Mendes, Manuel Bandeira, Fernando Pessoa, Camões, Homero, Mário Faustino, Dylan Thomas, Rimbaud, Baudelaire, Octavio Paz, Mallarmé, Paul Celan, Henri Michaux, René Char, Bashô, cummings, Blaise Cendrars, Kaváfis, Maiakóvski, Jorge Luis Borges, Robert Stock, García Lorca, Lautréamont, Ungaretti, Trakl, Blake, André de Bouchet, as vanguardas, o Concretismo. $\quad$ E Guimarães Rosa (Grande Sertão: Veredas), D. H. Lawrence, Henry Miller, Henry Thoreau, Clarice Lispector, Dostoiévski, Thomas Hardy (Judas, o Obscuro), Kazantzákis, Hermann Hesse, Romain Rolland, Thomas Mann, Flaubert, Malcolm Lowry, Hermann Broch, Em Busca do Tempo Perdido, de Proust, o Dom Quixote, Melville, Shakespeare, Mircea Eliade, Chuan-Tzu, o Zen-Budismo, I Ching, Lao-Tzu, O Livro Tibetano dos Mortos, o BhagavadGita, a Bíblia.

E Aristóteles, Platão, Nietzsche, Heidegger (Acheminement Vers la Parole, Hölderlin y la Esencia de la Poesia), Derrida, Gilles Deleuze, Todorov, Pound ( $A B C$ da Literatura e A Arte da Poesia), Valéry (M. Teste). E Damaso Alonso, Carlos Busoño, Roman Jakobson, Auerbach, Roland Barthes, Georges Bataille, T. S. Eliot, Walter Benjamin, George Steiner, os Manifestos Surrealistas, Max Bense, Benedito Nunes, José Guilherme Merquior, Antonio Candido, Ernest Fenollosa, Haroldo de Campos, Jean Starobinski, Saussure, Leo Spitzer.

Isso não é receita para jovens poetas, o que eles deveriam ler etc. É o meu caso e só. Mas acho que um poeta de hoje deve palmilhar por aí. Creio que esse é, pelo menos, o cerne de uma compreensão e de um amor pela poesia. Não esqueci de incluir na lista o óbvio: os dicionários, principalmente os etimológicos, os analógicos, os de mitologia, os botânicos, os de mecânica celeste, os históricos, culinários, os almanaques e catálogos, e qualquer coisa do chão, como acha o Manoel de Barros.

In: Diário do Pará. Belém, $1^{\text {o }}$ de maio de 2001. 